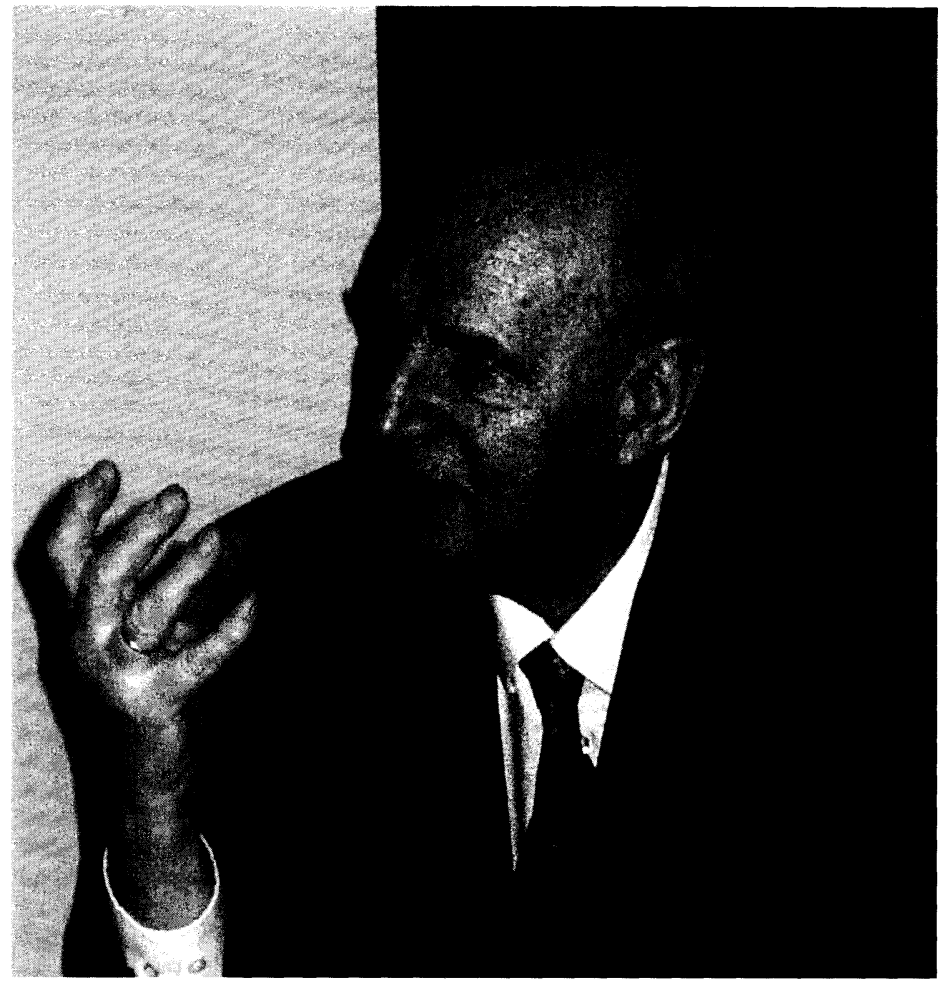

Sigurd Aa. Aarnes

12/2 1924 - 17/1 2007

(privatfoto) 


\title{
Sigurd Aa. Aarnes in memoriam
}

\author{
Af K. E. Bugge
}

Den 17. januar i år døde Sigurd Aa. Aarnes i en alder af knap 83 år. Selv om han gennem hele sit professionelle liv levede og virkede $\mathrm{i}$ afstand fra Danmark, opretholdt han igennem et halvt århundrede forbindelsen med Grnndtvigforskningen og bidrog til dens udvikling. Emnet for hans disputats fra 1961 var Grundtvigs historiesyn. Dette værk efterfulgtes af adskillige artikler og anmeldelser, der belyser Grundtvigs virke og eftervirkninger. I 1983 bidrog Aarnes til den af Christian Thodberg og Anders Pontoppidan Thyssen redigerede udgivelse N. F. S. Grundtvig. Tradition and Renewal (på flere sprog), ligesom han var en selvskreven gæst ved jubilæumsarrangementerne i dette minderige år. Endelig deltog han i 1987-92 i de Liselundseminarer, hvor man drøftede de grundlæggende principper for den nye tyske Grundtvig-udgave, herunder de vigtige spørgsmål om tekstudvælgelse og kommentering. I alle disse sammenhænge ydede han en grundigt forberedt og påskønnet indsats.

Sigurd Aarnes blev født i Oslo i 1924. På baggrund af en tidlig interesse for litteratur var det naturligt for ham, at hans universitetsstudier førte frem til sproglig-historisk embedseksamen (1950). Efter nogle år at have virket som gymnasielærer blev han i 1962 knyttet til Nordisk Institutt ved Universitetet i Bergen først som vikar, dernæst som lektor og fra 1988 som professor i nordisk litteraturhistorie. De sidste år ved universitetet tilbragtes i en stilling som seniorstipendiat. Om hans flid vidner, at der ved hans død forelå en færdigt udarbejdet tekstkritisk udgave af Bjørnsons Synnøve Solbakken. Bogen forventes at udkomme i løbet af indeværende år.

At en ung norsk litteraturforsker vælger at skrive disputats om en så udpræget dansk forfatter som Grundtvig, virker umiddelbart overraskende. I en artikel fra 1994, hvor han gør rede for sine tidlige studier, har Aarnes da også oplyst, at afhandlingen blev skrevet "i stor faglig isolation". Til hans valg af emne bidrog især to faktorer. Dels var i løbet af 1950'erne studiet af "idéhistorie" genstand for stærkt stigende interesse. Det samme var tilfældet her i Danmark, hvor Svend Erik Stybes Idéhistorie udkom i tre udgaver i løbet af årene 1961-66, og Lund, Pihl og Sløks De europceiske ideers historie kom i hele seks oplag i 1962-67. Ved universitetet i Oslo repræsenteredes fagområdet af professor A. H. Winsnes, der aktivt støttede Aarnes's studier på dette felt. At det så netop var Grundtvigs forfatterskab, der blev genstand for hans studier, skyldes andre faktorer af mere personlig art. Hans allerede nævnte tidlige interesse for litteratur gik efter hans egen 
oplysning tilbage til den omstændighed, at der i hjemmet forefandtes en betydelig bogsamling, hvor dansk-norske klassikere fra 19. århundrede var fyldigt repræsenteret.

I årene 1958-60 kunne Aarnes med støtte af et stipendium bevilget af Norges allmenvitenskapelige Forskningsråd samle sig om studiet af Grundtvig. I den anledning dukkede han en dag op på Det Kongelige Biblioteks læsesal, hvor han hurtigt blev bekendt med en række Grundtvig-forskere. Helge Toldberg, der døde i juni 1964, var dengang endnu særdeles aktiv og en næsten daglig gæst på læsesalen. Med sin vanlige energiske hjælpsomhed bistod Toldberg Aarnes med at finde rundt i Grundtvig-arkivet og lærte ham at læse Grundtvigs håndskrift. Den stilfærdige og utroligt vidende bibliograf Steen Johansen bistod ham med hensyn til at finde frem til og vurdere de forskellige udgaver af Grundtvigs skrifter. Endelig fik han mulighed for grundige samtaler med William Michelsen, hvis disputats, Tilblivelsen af Grundtvigs historiesyn, var udkommet i 1954, og som for Aarnes selvsagt var et vigtigt værk at studere og tage stilling til.

Men også andre bekendtskaber blev stiftet og venskaber knyttet. Det var netop i de år, at der arbejdedes intensivt med udgivelsen af Registrant over N. F. S. Grundtvigs Papirer, hvoraf de første 20 af værkets i alt 30 bind udkom i 1957-60. På Det Kongelige Biblioteks læsesal kunne Aarnes ikke blot træffe udgavens yngre medarbejdere, der boede i København, men også - om end sjældnere - både Kaj Thaning og Gustav Albeck, der kom tilrejsende fra henholdsvis Fyn og Jylland. Kort sagt, det var noget af et held for Aarnes, at han dumpede ned i dette forskningsmiljø i dets måske mest blomstrende periode. Efter hans eget udsagn var det en oplevelse, der stod i grel modsætning til hans indledende studier "i stor faglig isolation".

I slutningen af 1961 forelå disputatsen under titlen Historieskrivning og livssyn hos Grundtvig. En undersøkelse af to-verdensmotivet $i$ verdenskrønikene (335 s.). Ved disputatshandlingen 12. maj 1962 var daværende lektor i Roskilde, den førnævnte dr.phil. William Michelsen første officielle opponent. Anden officielle opponent var dr.philos. Paulus Svendsen, Winsnes' efterfølger som professor i idéhistorie ved universitetet i Oslo. Ex auditorio opponerede professor Gustav Albeck fra Århus. Michelsens opposition blev siden trykt i Grundtvig-Studier 1965, der for øvrigt også indeholdt en afhandling af Aarnes, "Omkring Grundtvigs historieskrivning - status og fremtidsperspektiver" (s. 37-48).

Til karakteristik af Aarnes's profil som Grundtvig-forsker vil det være hensigtsmæssigt at skitsere disputatsens opbygning og hovedtanker. I det første af afhandlingens syv kapitler gøres rede for forfatterens formål, som er at levere en strukturanalyse af de bærende 
tankegange i Grundtvigs Verdenskrøniker af 1812, 1814 og 1817. Disse værkers strukturelle ejendommelighed er ifølge Aarnes det tilgrundliggende to-verdensmotiv, dvs. modsætningen mellem åndens og legemets to verdener. Dette motiv omfatter dels en vertikalt orienteret tankemodel, der kan føres tilbage til Platons idélære, dels en aristotelisk-romantisk organismeforestilling. Motivet har således både et kosmologisk aspekt, der angiver dets verdensbillede, og et ontologisk, der angår menneskets bevidstheds- og sjæleliv. Derudover rummer motivet et personligt-eksistentielt aspekt, der vedrører historiker-holdningen. I kapitel II beskrives to-verdensmotivets tilblivelse hos Grundtvig under hans romantiske vækkelse på Langeland. På denne baggrund analyseres i kapitel III og IV de bærende tankegange i Verdenskrønikerne fra 1812 og 1814. Verdenskrøniken fra 1817 behandles i kapitel V; ifølge Aarnes afspejles allerede i dette værk den for Grundtvigs senere historieskrivning karakteristiske sondring mellem en "græsk" og en "hebraisk" tænkemåde. I kapitel VI belyses det personligt-eksistentielle perspektiv af to-verdensmotivet. Konkluderende sammenfatter Aarnes sin opfattelse i den prægnante formulering, at for Grundtvig er historieskrivning om fortiden en handling i nutiden for fremtiden (s. 314). I det afsluttende kapitel VII foretages et strejftog op i det senere forfatterskab. I 1823-25 opgiver Grundtvig ifølge Aarnes modstillingen af de to verdener og når frem til et livssyn, hvor evigheden gennemstråler det timelige, således at modstillingen mellem de to verdener afløses af en dyb harmoni og enhed imellem dem. I denne vurdering tilslutter Aarnes sig C. I. Scharlings opfattelse i bogen Grundtvig og Romantiken (1947).

Med henblik på en nærmere karakteristik af Aarnes's standpunkt vil det være hensigtsmæssigt at præcisere hans stilling til Michelsens opfattelse af Grundtvigs historiesyn. Her møder man både ligheder og forskelle. Aarnes er enig med Michelsen i dennes forbehold over for Thanings tale om, at Grundtvig i sin Haandbog $i$ Verdens-Historien fra 1830 'erne gør sig til talsmand for et sekulariseret historiesyn (Grundtvig-Studier 1965, 44; Kirke og Kultur, 1964, 250 f.)). Et andet vigtigt lighedspunkt er, at både Michelsen og Aarnes arbejdede idéhistorisk. Det gjorde de imidlertid på hver sin måde. Michelsens tilgang kan karakteriseres som historisk-genetisk. Det vil sige, at han har interesseret sig for tilblivelsen af Grundtvigs historiesyn, jf. titlen på hans disputats fra 1954. For ham var det vigtigt at få fastslået, hvilke ældre forfattere Grundtvig i denne proces har været påvirket af med hensyn til tankegang og udtryksmåde. I modsætning hertil har Aarnes arbejdet systematisk-analytisk med særligt henblik på tankernes struktur. Denne forskel bør dog ikke urgeres for kraftigt. Også Michelsen arbejdede med strukturanalyse, hvilket bl.a. fremgår 
af den rolle, Bibelens kaldæiske verdensbillede og tanken om de fire monarkier spiller i hans analyser. Og også Aarnes rettede søgelyset mod idéernes udvikling op igennem de behandlede værker.

Omfanget og arten af Aarnes's øvrige forfatterskab gennem årene fra 1953 til 1996 får man et udmærket indtryk af ved at kaste et blik på den bibliografi, der afslutter bogen $\AA$ dikte en nasjon fra 1997 (s. 230239). Af gode grunde har bibliografien dog ikke kunnet medtage hans udførlige anmeldelse af Ole Vinds disputats, "Grundtvigs historiefilosofi til kritisk vurdering" (Grundtvig-Studier 1999, 236-240). Bibliografien bekræfter Aarnes's egen bedømmelse: At hans forfatterskab er samlet om to hovedemner: (1) Den dansk-norske fælleslitteratur, og (2) litteraturens og digtningens betydning i den nationale bevidstgørelsesproces, man med et nyere udtryk har kaldt "nation-building". Under det første emne er det først og fremmest Aarnes's arbejde med Grundtvig og grundtvigianismen, der i nærværende sammenhæng påkalder sig interesse. Ud over disputatsen og de nævnte artikler lægger man især mærke til afhandlingen "Grundtvig og Norge - noen hovedlinjer" (Grundtvig-Studier 1993, 191-197). Her fortsætter og uddyber Aarnes Anders Skrondals tidligere studier, der foreligger i dennes store værk Grundtvig og Noreg fra 1929. Selv om den kirkelige grundtvigianisme i løbet af de sidste årtier af 1800-tallet blev "knust under vægten af en samlet pietistisk opposition", finder man ikke desto mindre, at Grundtvigs salmer indtager en solid plads i den norske salmebog. Her står man over for det fænomen, at der i Norge ofte er "en viss avstand mellom den teologien som ligger til grunn for prestens preken og den som menigheden synger ut med Grundtvig" (A dikte..., 53). De vigtigste af de øvrige områder, hvor en Grundtvig-indflydelse kan spores, er folkehøjskolen, nynorsktraditionen og de frie ungdomsforeninger.

Under det andet af de nævnte emner har Aarnes flere gange fremhævet, at selve dette, at digtere har spillet en særlig rolle for udviklingen af national selvbevidsthed, er karakteristisk for de nordiske lande. Efter Aarnes's opfattelse synes Norge imidlertid i denne henseende at være gået nogle skridt længere end de andre. I Norge møder man ikke blot digternes navne på veje og deres portrætter på pengesedler. Man har endog opkaldt tunneler og olieplatforme efter de store digtere. Og i Oslo er den centrale Eidsvoll plass "til trengsel" fyldt med statuer af digtere, ikke af konger og generaler. Via Bjørnson har Grundtvig også i denne særlige sammenhæng spillet en rolle.

Vedrørende Aarnes's øvrige forfatterskab skal her blot nævnes, at hans litteraturhistoriske studier er gode at få forstand af, og hans grundige udredning af 17. maj-festens historie er fængslende læsning. 
Hans studier over den klassiske litteraturs indslag i moderne reklamesprog er både lærerige og underholdende. Inden for Grundtvigforskningen er det imidlertid hans årelange aktive medleven $\mathrm{i}$ det særlige miljø, der samles omkring Grundtvig-Selskabet, man mindes ved hans bortgang. Hans glæde ved studieophold i Danmark og ved samvær i selskabets regi var åbenlys og smittende. Vi vil savne hans grundige indlæg, hans stilfærdige lune og hans trofaste venskab. 